\title{
SOIL RESOURCES, MICROBIAL ACTIVITY, AND PRIMARY PRODUCTION ACROSS AN AGRICULTURAL ECOSYSTEM
}

\author{
G. Philip Robertson, ${ }^{1,2}$ Katherine M. Klingensmith, ${ }^{1,4}$ Michael J. Klug, ${ }^{1,3}$ Eldor A. Paul, ${ }^{2}$ \\ JAMES R. CRum, ${ }^{2}$ AND Boyd G. Ellis ${ }^{2}$ \\ ${ }^{1}$ W.K. Kellogg Biological Station, Michigan State University, Hickory Corners, Michigan 49060-9516 USA \\ ${ }^{2}$ Department of Crop and Soil Sciences, Michigan State University, East Lansing, Michigan 48824 USA \\ ${ }^{3}$ Department of Microbiology, Michigan State University, East Lansing, Michigan 48824 USA
}

\begin{abstract}
The degree to which soil resource availability is linked to patterns of microbial activity and plant productivity within ecosystems has important consequences for our understanding of how ecosystems are structured and for the management of systems for agricultural production. We studied this linkage in a 48-ha site in southwest Michigan, USA, that had been cultivated and planted to row crops for decades. Prior to seeding the site to genetically identical soybean plants (Glycine max) in early spring, we removed soil samples from $\approx 600$ locations; plant biomass was harvested from these same locations later in the season. Soil samples were analyzed for physical properties (texture, bulk density), chemical properties (moisture, $\mathrm{pH}$, total $\mathrm{C}$, total $\mathrm{N}$, inorganic $\mathrm{N}$ ), and biological attributes (microbial biomass, microbial population size, respiration potential, and nitrification and $\mathrm{N}$-mineralization potentials). Plant analyses included biomass and $\mathrm{C}$ and $\mathrm{N}$ contents. Soil resource variability across this long-cultivated site was remarkably high, as was variability in microbial activity and primary productivity. In almost all cases variability exhibited a strong spatially explicit structure: for most properties and processes $>50 \%$ of sample variance was spatially dependent at a scale of 5-60 m. Exceptions included microtopography, soil $\mathrm{pH}$, and inorganic $\mathrm{P}$, which were spatially dependent across the entire 1-1200 $\mathrm{m}$ range of separation distances examined in this study, and the culturable-bacteria population, which was not spatially autocorrelated at any scale examined. Both topographic relief and soil $\mathrm{pH}$ exhibited strongly nested structures, with autocorrelation occurring within two (topography) or more $(\mathrm{pH})$ distinct ranges. Multiple regression analysis showed surprisingly little correlation between biological processes (soybean productivity, soil $\mathrm{N}$ turnover, soil respiration), and static soil properties. The best predictor of soybean biomass at late reproductive stages $\left(r^{2}=0.42\right)$ was a combination of nitrate $\mathrm{N}$, bulk density, inorganic $\mathrm{P}, \mathrm{N}$-mineralization rates, and $\mathrm{pH}$. Overall, results suggest a remarkable degree of spatial variability for a pedogenically homogeneous site that has been plowed and cropped mostly as a single field for $>100 \mathrm{yr}$. Such variability is likely to be generic to most ecosystems and should be carefully evaluated when making inferences about ecological relationships in these systems and when considering alternative sampling and management strategies.
\end{abstract}

Key words: agricultural systems; cropping systems; geostatistics; kriging; microbial biomass; Michigan, USA; soil biology; soil chemistry; spatial variability; variograms.

\section{INTRODUCTION}

Soil resources can vary markedly and predictably across both undisturbed and intensively managed ecosystems. Recent studies have shown that within-site sample variance commonly ascribed to random error is often spatially dependent at scales relevant to individual plants (e.g., Webster 1985, Robertson et al. 1988, Hook et al. 1991, Lechowicz and Bell 1991, Jackson and Caldwell 1993, Gross et al. 1995, Schlesinger et al. 1996). Moreover, at least some of this spatial structuring appears to be dynamic, changing over both

Manuscript received 11 August 1995; revised 13 October 1995; accepted 13 February 1996.

${ }^{4}$ Present address: Keuka College, Keuka Park, New York 14478-0098 USA. pedogenic (Walker and Ruhe 1968) and ecological (Robertson et al. 1993) time scales.

The degree to which soil resource variability affects microbial activity and primary production has implications for both our understanding of ecosystem structure and our management of ecosystem resources. Soil variability can affect the net response of ecosystems to different management practices, which in turn will affect both the economic and environmental impact of management. The recent development of site-specific farming practices (e.g., Robert et al. 1993, Fiez et al. 1994) is a case in point. Site-specific farming involves the application of agricultural chemicals at differential rates across specific fields, motivated by the economic need to reduce on-farm chemical costs and the environmental need to minimize the leakage of fertilizers and pesticides to adjacent and downstream ecosystems. 
Site-specific farming depends directly on knowledge of spatial variability within the site, but exactly how much and what kind of knowledge is required for effective site-specific management is largely unknown for most if not all production systems.

We have, in general, a poor basic understanding of the causes and consequences of soil resource heterogeneity for most ecosystems regardless of management status. The degree to which heterogeneity reflects physical features of the environment such as microtopography or soil texture, vs. past vegetation or disturbance history, will likely vary by site, as will the effects of heterogeneity on contemporary community structure and on ecosystem response to management or other disturbance. In some environments heterogeneity may in fact create ecological feedbacks that promote the development of even further heterogeneity (e.g., Schlesinger et al. 1990, Tilman and Wedin 1990).

Characterizing site heterogeneity is difficult because of the need for a sufficient number of samples to characterize the site and the need for sufficient analytical replication to ensure that the variability encountered is not an artifact of the sampling itself. Consequently, information about soil spatial variability is available from only a very few sites world-wide, and for those sites for which we have information, data are usually limited to a single set of two or three physiochemical soil characteristics. In very few cases do we have corresponding information about plant, microbial, or invertebrate populations, and for no sites do we have comprehensive information for an entire suite of physical, chemical, and biological properties.

We designed the present study to address the general need for further basic information about soil resource heterogeneity and to address the specific need for information about heterogeneity in agricultural systems. We chose what we expected to be one of the most homogeneous sites available in order to simplify and clarify interrelationships among the properties and processes examined. This site-a 48-ha field planted uniformly to a single crop genotype-also provided a means for judging the integrated impact of soil resource availability on plant productivity. We found a remarkable degree of spatial structuring in this simplified ecosystem, and less correspondence than we expected between plant productivity and the soil attributes examined.

\section{Study Site}

Our study site was the 48-ha main experimental area of the W.K. Kellogg Biological Station (KBS) LongTerm Ecological Research (LTER) site in southwest Michigan, USA $\left(85^{\circ} 24^{\prime} \mathrm{W}\right.$ longitude, $42^{\circ} 24^{\prime} \mathrm{N}$ latitude). This site is in the southern Great Lakes region of the USA, in the transition zone between southern oak-hickory (Quercus-Carya) and northern hardwood vegetation zones (Kuchler 1964). KBS is on the pitted outwash plain of the morainic system left by the last

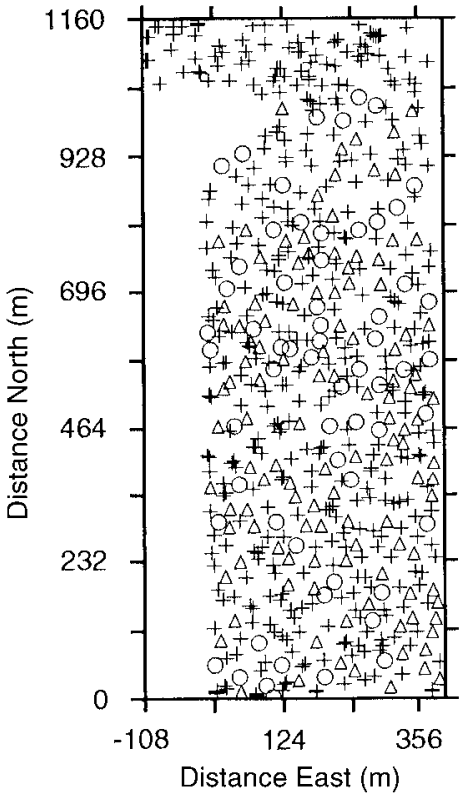

FIG. 1. Sample locations within the 48 -ha sampling area. Symbols refer to sample class: $+=$ locations sampled for all variates ( $n=377$ locations), $\bigcirc=$ additional locations sampled for selected variates as noted in Tables 1-3, including elevation ( $n=576$ total locations), and $\Delta=$ additional locations sampled for elevation only ( $n=796$ total locations).

retreat of the Wisconsin glaciation, $\approx 12000 \mathrm{yr}$ BP. Soils in the area developed on glacial outwash; soils at the site are Typic Hapludalfs, either fine-loamy, mixed, mesic Kalamazoo series or coarse-loamy, mixed, mesic Oshtemo series (Whiteside et al. 1959, Mokma and Doolittle 1993a, b; H. P. Collins et al., unpublished manuscript). Mean annual temperature is $9.4^{\circ} \mathrm{C}$; precipitation ( $\approx 920 \mathrm{~mm}$ annually) is spread evenly throughout the year, and potential evapotranspiration exceeds precipitation (30-yr mean) for three months per year (Crum et al. 1990).

Prior to the present study the site had been cultivated for a century or more, since 1962 by Michigan State University. In the most recent 10 -yr period, the site had been planted to continuous corn (Zea mays) except for 1983-1986 when northern portions of the site were planted to alfalfa (Medicago sativa) and soybeans (Glycine max). In 1987, the year prior to this study, the entire site was planted to corn, followed by fall-planted rye (Lolium sp.). Soybeans were planted in 1988 after first plowing under the rye cover crop, and were managed normally except that neither herbicides nor fertilizers were applied during the 1988 field season. Yields on site are typically above the county average of $7.3 \times 10^{3} \mathrm{~kg} / \mathrm{ha}$ (116 bushels/acre) for corn grain and $2.3 \times 10^{3} \mathrm{~kg} / \mathrm{ha}$ (37 bushels/acre) for soybeans.

\section{Methods \\ Sampling}

In mid-May, following plowing and secondary tillage but prior to soybean planting, we marked 600 sam- 
TABLE 1. Soil physical characteristics over the 48-ha sample site in southwest Michigan. All values are calculated on the basis of $n$ sample locations; values at each sample location are based on $1-3$ analytical replicates per location. $\mathrm{CV}=$ coefficient of variation.

\begin{tabular}{|c|c|c|c|c|c|c|c|c|c|}
\hline \multirow[b]{2}{*}{ Characteristics } & \multirow[b]{2}{*}{ Units } & \multirow[b]{2}{*}{ Mean } & \multirow[b]{2}{*}{ SD } & \multirow[b]{2}{*}{$\mathrm{CV}(\%)$} & \multicolumn{2}{|c|}{ Range } & \multirow[b]{2}{*}{ Skewness } & \multirow[b]{2}{*}{ Kurtosis } & \multirow[b]{2}{*}{$n$} \\
\hline & & & & & Minimum & Maximum & & & \\
\hline Topographic relief & $\mathrm{m}$ & 287.4 & 1.82 & 0.6 & 283.6 & 291.6 & 0.681 & -0.334 & 597 \\
\hline Bulk density & $\mathrm{g} / \mathrm{cm}^{3}$ & 1.29 & 0.10 & 7.8 & 0.89 & 1.60 & -0.745 & 1.450 & 406 \\
\hline Gravel content & $\mathrm{mg} / \mathrm{cm}^{3}$ & 52.6 & 50.4 & 95.8 & 1.0 & 401.0 & $-0.355 \dagger$ & $1.673 \dagger$ & 406 \\
\hline Sand content & $\%$ & 43.4 & 10.6 & 24.4 & 8.8 & 77.7 & 0.347 & 0.934 & 408 \\
\hline Silt content & $\%$ & 39.5 & 9.0 & 22.8 & 7.7 & 63.7 & -0.714 & 0.776 & 408 \\
\hline Clay content & $\%$ & 17.1 & 3.0 & 17.5 & 10.0 & 28.0 & 0.467 & 0.638 & 408 \\
\hline
\end{tabular}

$\dagger$ Calculated following lognormal transformation $[\ln (z)]$ of original values.

ple locations across the site (Fig. 1). Locations were chosen to optimize both autocorrelation analysis, which requires a reasonable number of samples separated by small separation distances, and mapping, which requires sample locations to be more or less evenly dispersed across the field. We specified 192 sample locations in a stratified unaligned grid design (Webster and Oliver 1990) having $50 \times 50 \mathrm{~m}$ cells across the site; the remaining samples were placed randomly as singlets, doublets, and triplets. Points in the doublets and triplets were separated from one another by $1 \mathrm{~m}$. All sample locations were marked with a flag that remained in place until soybean harvest. Prior to harvest the exact location $( \pm 10 \mathrm{~cm}$ ) of each flag was determined using laser stratigraphy that also provided information on topographic relief with $\pm 2 \mathrm{~cm}$ precision. Because of cost and logistical considerations, not all analyses were performed on samples from all locations; as noted in Tables 1-3 in the Results, sampling intensity ranged from 361 to 597 samples per variate.

\section{Analyses}

Soils were sampled over a 2-d period in late May. Approximately $25 \mathrm{~cm}$ to the northeast and $25 \mathrm{~cm}$ to the northwest of each flagged sample location we removed two $15-\mathrm{cm}$ depth soil cores using a $7.5 \mathrm{~cm}$ diameter root sampler (Elkjamp, Wageningen, The Netherlands). Compaction of the cores was minimal $(<0.5$ $\mathrm{cm}$ ). Cores were composited by location and refrigerated within $1 \mathrm{~h}$ for transport to the laboratory.

In the laboratory, each of the sample composites was weighed and then put through a 4-mm sieve to remove gravel and to homogenize the soil for subsampling. Gravel was discarded after weighing, and sieved soils were refrigerated immediately. Within $3 \mathrm{~d}$ of sampling, sieved soils were subsampled for individual analyses.

From each soil composite two 10-g subsamples were extracted in $100 \mathrm{~mL}$ of $2 \mathrm{~mol} / \mathrm{L} \mathrm{NaCl}$ for later analysis of $\mathrm{NH}_{4}{ }^{+}, \mathrm{NO}_{2}{ }^{-}$, and $\mathrm{NO}_{3}{ }^{-}$by continuous flow analysis (Alpkem 1992). A 1-kg subsample was removed and dried at $65^{\circ} \mathrm{C}$ for gravimetric moisture analysis. Later this dried soil was subsampled for $\mathrm{pH}$, inorganic phosphorus, and total carbon and nitrogen analyses. For $\mathrm{pH}$, duplicate subsamples were analyzed in a 2:1 water:soil suspension. Triplicate subsamples were crushed and analyzed for total carbon and nitrogen using a CarloErba CN analyzer.

For phosphorus analyses, triplicate 5-g subsamples were extracted in $50 \mathrm{~mL}$ of Bray's P-1 extractant (Olsen and Sommers 1982) and the extractant was then subjected to flow-injection analysis. All $\mathrm{N}$ and $\mathrm{P}$ results are expressed as unit mass per gram dry soil. A 40-g aliquot of the remaining undried soil composite was immediately subsampled for soil microbial biomass using the chloroform fumigation technique (Horwath and Paul 1994, Horwath et al. 1997). Another subsample was removed for determination of the population size of culturable bacteria using serial dilutions on a soilextract agar. A third subsample was removed for nematode trophic-group analysis (Robertson and Freckman 1995).

Of the remaining undried composite, $400 \mathrm{~g}$ was placed in a $2-\mathrm{L}$ polyethylene bag and incubated in a darkened and humidified constant-temperature room at $25^{\circ} \mathrm{C}$. After $21 \mathrm{~d}$, three 10 -g subsamples from each of the composites were extracted and analyzed for inorganic nitrogen as described in the paragraph above. The net increase in total inorganic $\mathrm{N}$ over the incubation interval was used to indicate the soil's $\mathrm{N}$-mineralization potential; the net increase in nitrate $\mathrm{N}$ over this period was used as an index of net nitrification. We estimated microbial activity by measuring $\mathrm{CO}_{2}$ production during a 24-h incubation of 10-g aliquots of fresh soil in sealed tubes. All measures of soil microbial activity were performed using soils at field moisture levels, i.e., without additional water.

At the end of the growing season, prior to leaf senescence, we harvested soybean plants at a subset of the original sample locations. At each location we sampled $1 \mathrm{~m}$ of crop row by clipping plants at ground level. In the lab, plants were counted, dried at $65^{\circ} \mathrm{C}$, and weighed. Each of the plant composites was then ground in an impact mill and subsampled in triplicate for total $\mathrm{C}$ and $\mathrm{N}$ analysis as described above in this Analyses section. Weeds made up $0-5 \%$ of total plant biomass in all locations across the field (K. Gross and K. Renner, personal communication); we thus use the terms plant biomass and soybean biomass interchangeably in this paper.

For all soil and plant analyses except moisture and 
TABle 2. Soil chemical characteristics across the 48-ha Michigan farmland site. See Table 1 legend for further details.

\begin{tabular}{|c|c|c|c|c|c|c|c|c|c|}
\hline \multirow{2}{*}{$\begin{array}{l}\text { Character- } \\
\text { istics }\end{array}$} & \multirow[b]{2}{*}{ Units } & \multirow[b]{2}{*}{ Mean } & \multirow[b]{2}{*}{ SD } & \multirow[b]{2}{*}{$\mathrm{CV}(\%)$} & \multicolumn{2}{|c|}{ Range } & \multirow[b]{2}{*}{ Skewness } & \multirow[b]{2}{*}{ Kurtosis } & \multirow[b]{2}{*}{$n$} \\
\hline & & & & & Minimum & Maximum & & & \\
\hline Moisture & $\%$ fresh mass & 12.10 & 1.76 & 14.9 & 6.6 & 20.1 & $0.505^{1}$ & $1.36^{1}$ & 577 \\
\hline Acidity & $\mathrm{pH}$ & 6.68 & 0.47 & 7.0 & 4.67 & 7.56 & -2.30 & 5.32 & 553 \\
\hline Nitrate N & $\mu \mathrm{g} \mathrm{N} / \mathrm{g}$ & 7.73 & 3.04 & 39.3 & 1.9 & 20.8 & $-0.149 \dagger$ & $0.123 \dagger$ & 568 \\
\hline Mineral N & $\mu \mathrm{g} \mathrm{N} / \mathrm{g}$ & 10.87 & 4.13 & 40.0 & 3.1 & 28.2 & $0.070 \dagger$ & $0.138 \dagger$ & 563 \\
\hline Inorganic $\mathrm{P}$ & $\mu \mathrm{g} \mathrm{P} / \mathrm{g}$ & 71.1 & 24.5 & 34.5 & 19.8 & 146.6 & 0.374 & -0.263 & 549 \\
\hline Organic C & $\%$ dry mass & 1.08 & 0.22 & 20.4 & 0.50 & 2.10 & $0.459 \ddagger$ & $1.12 \ddagger$ & 405 \\
\hline $\mathrm{C}: \mathrm{N}$ & Ratio & 10.0 & 1.55 & 15.5 & 3.3 & 14.2 & -0.762 & 2.15 & 405 \\
\hline
\end{tabular}

$\dagger$ Following lognormal transformation $[\ln (z)]$ of original values.

$\ddagger$ Following lognormal transformation $[\ln (z+1)]$ of original values.

microbial biomass, the analytical coefficients of variation ( $n=2$ or 3 replicate analyses per sample location except $n=1$ for moisture and microbial biomass) were $\leq 10 \%$; samples outside of this range were reanalyzed or discarded. Analytical means were used for all statistical analyses.

\section{Statistical analysis}

Parametric statistics were performed using SYSTAT (Wilkinson et al. 1992) and SAS (SAS Institute 1985). Where necessary, data were lognormally transformed prior to analysis in order to better normalize probability distributions. Backtransformations followed Krige (1981). Geostatistical analyses (Webster 1985, Rossi et al. 1992, Robertson and Gross 1994) were performed using GS + (Gamma Design 1995). For variograms, semivariance values were grouped into discrete distance classes $10-15 \mathrm{~m}$ wide, with pairs of points in the first class separated by an average distance of $\approx 6 \mathrm{~m}$. For the variate sampled least intensively $(n=361$ sample locations), 77, 105, and 166 pairs, respectively, were included in the first through third distance classes; for the most intensively sampled variate $(n=597$ locations) the corresponding numbers were 180,712 , and 1273 pairs.

Variogram model fitting was performed via leastsquares analysis (Gamma Design 1995; cf. Cressie 1985). With two exceptions, variograms were fit to exponential models, which generally provided a better reduced sums-of-squares fit than did the other available models. The exceptions were topographic relief, for which a nested Gaussian model fit better, and soil $\mathrm{pH}$, which exhibited a nested spherical structure. For comparative purposes, all models were fit across a range of $200 \mathrm{~m}$, although a range of up to $1400 \mathrm{~m}$ is possible for data from this site. In all but three cases (topography, soil $\mathrm{pH}$, and inorganic $\mathrm{P}$ ) variogram sills approached total sample variance, $s^{2}$, within a separation distance of $<200 \mathrm{~m}$.

We use the proportion of model sample variance (the variogram asymptote or sill, or $C+C_{0}$ ) explained by structural variance $C$ as a normalized measure of spatial dependence for a particular variate. Where this proportion $\left(C /\left[C+C_{0}\right]\right)$ approaches 1 , spatial dependence is high: a large proportion of total sample variance, $s^{2}$, is spatially dependent. Where this proportion approaches 0 , apparent spatial dependence is low, indicating that measurement error is high or that spatial dependence occurs mainly at scales smaller than the average distance in the first lag (separation class) interval, in our case $6 \mathrm{~m}$. Where model sample variance $\left(C+C_{0}\right)$ does not approach total sample variance, $s^{2}$, spatial dependence may be occurring at distances greater than the range modeled (Barnes 1991).

Variate maps were produced using ordinary block kriging (Gamma Design 1995) with a block size of 2.5 $\mathrm{m}$ across the field and a $2 \times 2$ discretization grid within each block. Lognormally transformed data were backtransformed to original units prior to mapping.

\section{RESULTS}

Most soil physical characteristics ranged over an order of magnitude across the site, with coefficients of variation correspondingly high (Table 1). For example, gravel content ranged from 1 to $400 \mathrm{mg} / \mathrm{cm}^{3}$, and sand and silt each ranged from $\approx 8$ to $75 \%$. Topographic relief exhibited the least variation, with elevations ranging from 284 to $292 \mathrm{~m}$ and a coefficient of variation $(\mathrm{CV})=0.6 \%$. Except for gravimetric moisture, soil chemical characteristics exhibited similar variability (Table 2). The range of nitrate $\mathrm{N}$ as a proportion of soil dry mass was $2-20 \mu \mathrm{g} / \mathrm{g}$ and that of total mineral N 3-30 $\mu \mathrm{g} / \mathrm{g}$, with CVs of $40 \%$ in both cases. Organic $\mathrm{C}$ ranged from 0.5 to $2.1 \%$ of soil dry mass, and the soil C: $\mathrm{N}$ ratio from 3.3 to 14 . Inorganic $\mathrm{P}$ levels ranged from 20 to $147 \mu \mathrm{g} / \mathrm{g}$ P. Soil acidity ranged about three orders of magnitude, from $\mathrm{pH} 4.7$ to $\mathrm{pH}$ 7.6. Gravimetric moisture, on the other hand, varied only from 7 to $20 \%$ on a fresh-mass basis.

Culturable-bacteria population size, biomass, and activity (Table 3 ) also varied substantially across the site. Microbial population size was most variable, ranging two orders of magnitude, from $1.5 \times 10^{6}$ to $260 \times 10^{6}$ cells/g soil, with a CV of $92 \%$. Microbial biomass was least variable, with a one-order-of-magnitude range and a CV of $33 \%$. Soybean production (Table 3) was about as variable as microbial biomass across the site, ranging from 39 to $512 \mathrm{~g} / \mathrm{m}^{2}(\mathrm{CV}=35 \%)$.

Variograms show that all but one of the properties examined at this site were spatially dependent, though 
TABle 3. Biological properties of soil at the study site. Plants are soybeans (Glycine max). All N and P are expressed per unit soil dry mass. See Table 1 legend for further details.

\begin{tabular}{|c|c|c|c|c|c|c|c|c|c|}
\hline \multirow[b]{2}{*}{ Property } & \multirow[b]{2}{*}{ Units } & \multirow[b]{2}{*}{ Mean } & \multirow[b]{2}{*}{ SD } & \multirow[b]{2}{*}{$\mathrm{CV}(\%)$} & \multicolumn{2}{|c|}{ Range } & \multirow[b]{2}{*}{ Skewness } & \multirow[b]{2}{*}{ Kurtosis } & \multirow[b]{2}{*}{$n$} \\
\hline & & & & & Minimum & Maximum & & & \\
\hline \multicolumn{10}{|l|}{ Microbial properties } \\
\hline Culturable bacteria & $10^{5}$ cells $/ \mathrm{g}$ & 338.4 & 311.2 & 92.0 & 15 & 2600 & $0.254 \dagger$ & $0.608 \dagger$ & 377 \\
\hline Biomass C & $\mu \mathrm{g} / \mathrm{g}$ & 63.7 & 21.3 & 33.5 & 9.1 & 165.3 & $-1.21 \dagger$ & $3.31 \dagger$ & 361 \\
\hline Respiration & $\operatorname{ng~C} \cdot g^{-1} \cdot d^{-1}$ & 506.5 & 187.4 & 37.0 & 101.0 & 1284 & $-0.303 \dagger$ & $1.14 \dagger$ & 366 \\
\hline Net nitrification & $\mu \mathrm{g} \mathrm{N} \cdot \mathrm{g}^{-1} \cdot \mathrm{d}^{-1}$ & 0.446 & 0.171 & 38.3 & 0.03 & 1.64 & $0.894 \ddagger$ & $2.25 \ddagger$ & 514 \\
\hline Net $\mathrm{N}$ mineralization & $\mu \mathrm{g} \mathrm{N} \cdot \mathrm{g}^{-1} \cdot \mathrm{d}^{-1}$ & 0.431 & 0.172 & 39.9 & -0.12 & 1.42 & $0.434 \ddagger$ & $1.57 \$$ & 504 \\
\hline \multicolumn{10}{|l|}{ Plant properties } \\
\hline Biomass & $\mathrm{g} / \mathrm{m}^{2}$ & 237.5 & 83.3 & 35.1 & 38.9 & 512.1 & 0.275 & 0.19 & 363 \\
\hline $\mathrm{N}$ content & $\%$ & 3.36 & 0.46 & 13.7 & 1.71 & 4.67 & -0.407 & 0.69 & 378 \\
\hline
\end{tabular}

$\dagger$ Calculated following lognormal transformation $[\ln (z)]$ of original values

\$Calculated following lognormal transformation $[\ln (z+1)]$ of original values.

to different degrees. Among soil physical properties (Fig. 2), elevation, gravel content, and bulk density were all strongly autocorrelated within the 1-200 m range, with spatially structured variance accounting for up to $95 \%$ of total model sample variance (Table 4). Soil texture was less well-structured, with spatially dependent variance ranging from 18 to $44 \%$ of model
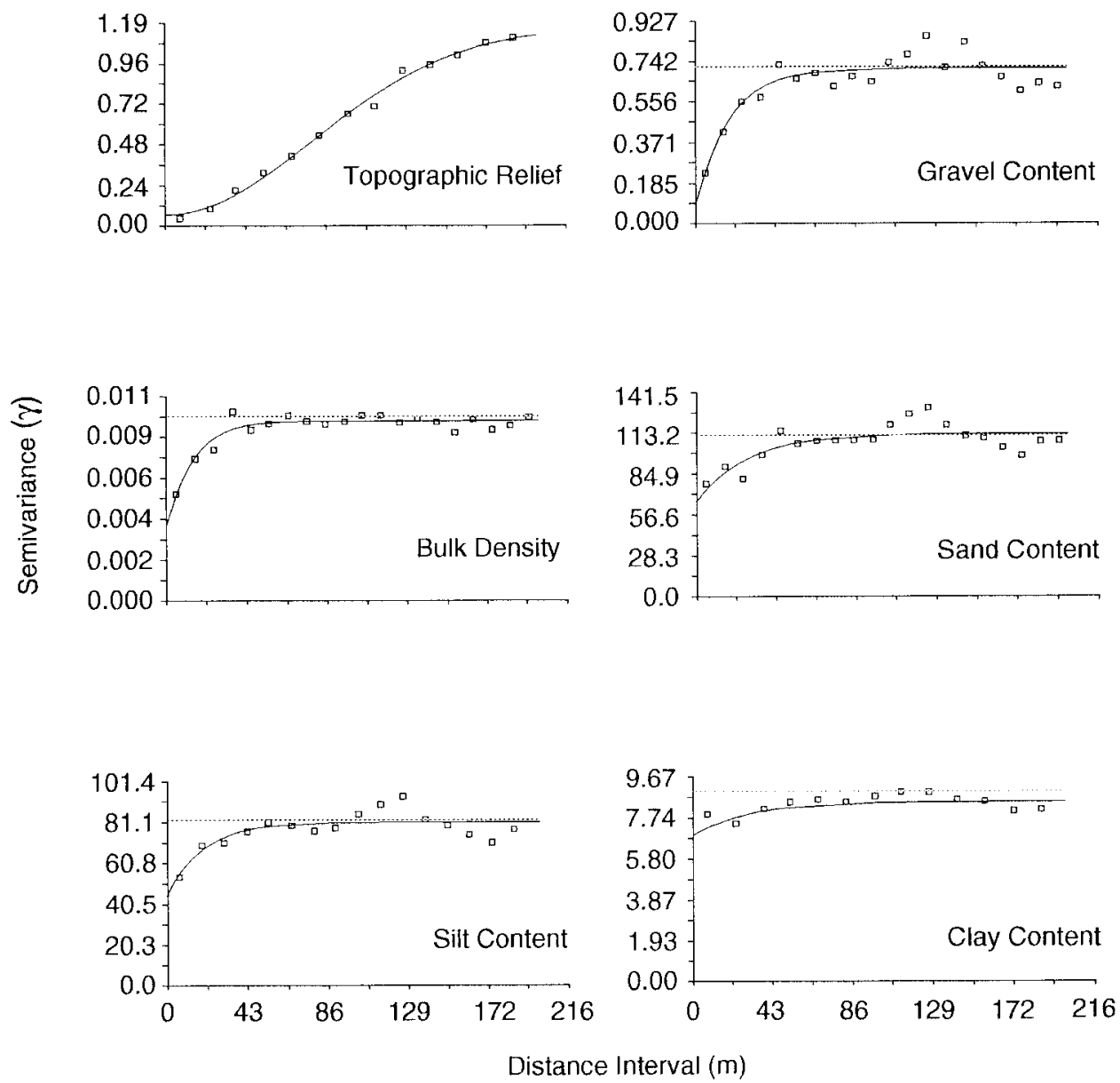

FIG. 2. Variograms for soil physical properties across the site. Horizontal dotted lines in each diagram indicate overall sample variance for each variate except for topographic relief, for which $s^{2}=3.32$. Model parameters appear in Table 4 . 
TABLE 4. Variogram model parameters and sample variance $\left(s^{2}\right)$ for soil physical properties across the study site.

\begin{tabular}{lcccc}
\hline \hline \multirow{2}{*}{ Property } & \multicolumn{4}{c}{ Model parameters } \\
\cline { 2 - 5 } & $C /\left(C_{0}+C\right)$ & Range $(\mathrm{m})$ & $r^{2}$ & $s^{2}$ \\
\hline Topographic relief $\dagger$ & 0.945 & 582. & 0.995 & 3.319 \\
Bulk density $\ddagger$ & 0.591 & 42.9 & 0.876 & 0.010 \\
Gravel content $\ddagger$ & 0.884 & 57.0 & 0.770 & $0.697 \|$ \\
Sand content $\ddagger$ & 0.415 & 86.1 & 0.584 & 111.6 \\
Silt content $\ddagger$ & 0.441 & 58.5 & 0.629 & 81.8 \\
Clay content $\ddagger$ & 0.178 & 93.6 & 0.443 & 9.1 \\
\hline
\end{tabular}

Notes: $C_{0}=$ nugget variance, $C /\left(C_{0}+C\right)=$ structural variance $C$ as a proportion of model sample variance, range $=$ distance over which structural variance is expressed. See Figs. 3 and 4 for variograms.

$\dagger$ Gaussian model: $\gamma(h)=C_{0}+C\left(1-e^{-h^{2} / a^{2}}\right)$, where $h=$ separation distance and $a=$ spatial range.

\$Exponential mode: $\gamma(h)=C_{0}+\left(C-C_{0}\right) \times\left(1-e^{-h / a}\right)$, where $h=$ separation distance and $a=$ range parameter; range $=3 a$.

$\|$ Skewness and kurtosis calculated following lognormal transformation $[\ln (z)]$ of original values.

pled range (Fig. 3) shows spatial dependence across the entire range.

Variograms for soil chemical properties (Fig. 4) showed a similar degree of spatial structure. Moisture, organic carbon, and soil $\mathrm{C}: \mathrm{N}$ ratio were most highly structured, with $85-95 \%$ of model sample variance spatially dependent within a $60-\mathrm{m}$ range of separation (Table 5). Soil nitrate $\mathrm{N}$, total mineral $\mathrm{N}\left(\mathrm{NH}_{4}{ }^{+}-\mathrm{N}+\mathrm{NO}_{3}{ }^{-}\right.$$\mathrm{N})$, and inorganic $\mathrm{P}$ were somewhat less structured, with $50-75 \%$ of model sample variance spatially dependent over a range of $90 \mathrm{~m}$. Except for $\mathrm{pH}$ and inorganic $\mathrm{P}$, model sample variance was very close to overall sample variance for each variate (Table 5).

Soil $\mathrm{pH}$ differs from other variates in that its variance, while highly structured, is nested at several levels within the sample range of $1100 \mathrm{~m}$. Within a range of $750 \mathrm{~m}$ (Fig. 5a) variance appears to be structured within as many as four distinct ranges: $0-120 \mathrm{~m}, 120-130 \mathrm{~m}$, $300-450 \mathrm{~m}$, and $450-750 \mathrm{~m}$, with most of the spatially structured variance within each range occurring at the beginning of the range interval. Variance appears to be spatially structured even beyond the maximum examined range of $1100 \mathrm{~m}$, however, as the variogram did not reach an asymptote even beyond $750 \mathrm{~m}$ (Fig. 5b). Inorganic P variance was similarly structured but with

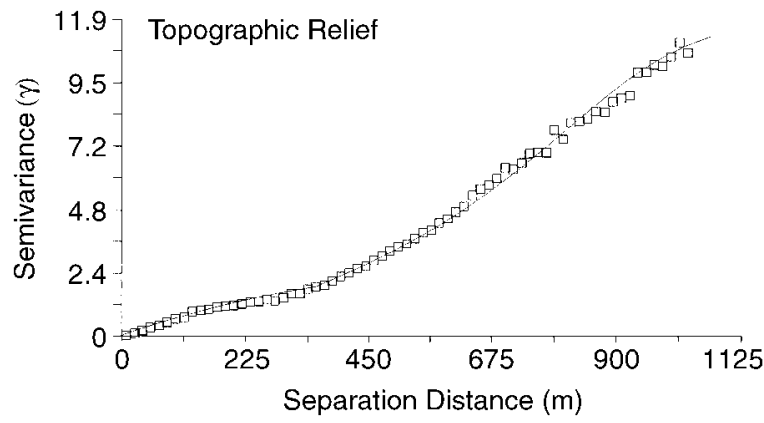

FIG. 3. Variogram for topographic relief across the entire range available. Contrast with $200-\mathrm{m}$ range in Figure 2. only two ranges: $75 \mathrm{~m}$ and $>1100 \mathrm{~m}$ (second range not shown).

None of the variation associated with the size of the culturable bacterial population appeared to be spatially structured (Fig. 6); structural variance as a proportion of model sample variance is zero for our sampling scale (Table 6). Other microbial properties exhibited greater spatial dependence at these scales: $>50 \%$ of the variation associated with microbial biomass and net nitrification potentials had a spatial component; likewise $30-40 \%$ of the variation associated with soil respiration potentials and net $\mathrm{N}$-mineralization potentials appeared to be spatially dependent. This dependence was expressed over a range of 20-30 m except for soil respiration potentials, for which dependence ranged to $60 \mathrm{~m}$. In all cases model sample variance was close to actual sample variance (Fig. 6).

Plant (soybean) biomass and $\mathrm{N}$ content were also spatially structured to a moderate degree across the site (Fig. 7). For biomass, $\approx 45 \%$ of model sample variance was spatially dependent to a range of $93 \mathrm{~m}$ (Table 6). Soybean N content was similarly structured (56\%) within a range of $51 \mathrm{~m}$.

Maps of selected soil and plant properties across the site (Figs. 8, 9) illustrate the spatial complexity suggested by variograms. Some properties such as topographic relief (Fig. 8a) exhibit a monotonic trend across the site, in this case a trend of higher elevation in the northwest corner that drops $6 \mathrm{~m}$ over the $1.4-\mathrm{km}$ distance to the southeast corner of the site. This trend can be loosely seen for soil texture (percentage sand, Fig. $8 b$ ), although more localized patch heterogeneity is equally evident. General trends are less apparent for soil nitrate (Fig. 8c) and total C (Fig. 8d), for which hectare-sized patches become prevalent.

$\mathrm{N}$ mineralization was very patchy across the site (Fig. 9a), as was microbial biomass (Fig. 9b), although in the latter case patchiness was superimposed on a general trend of higher values at the south end of the 

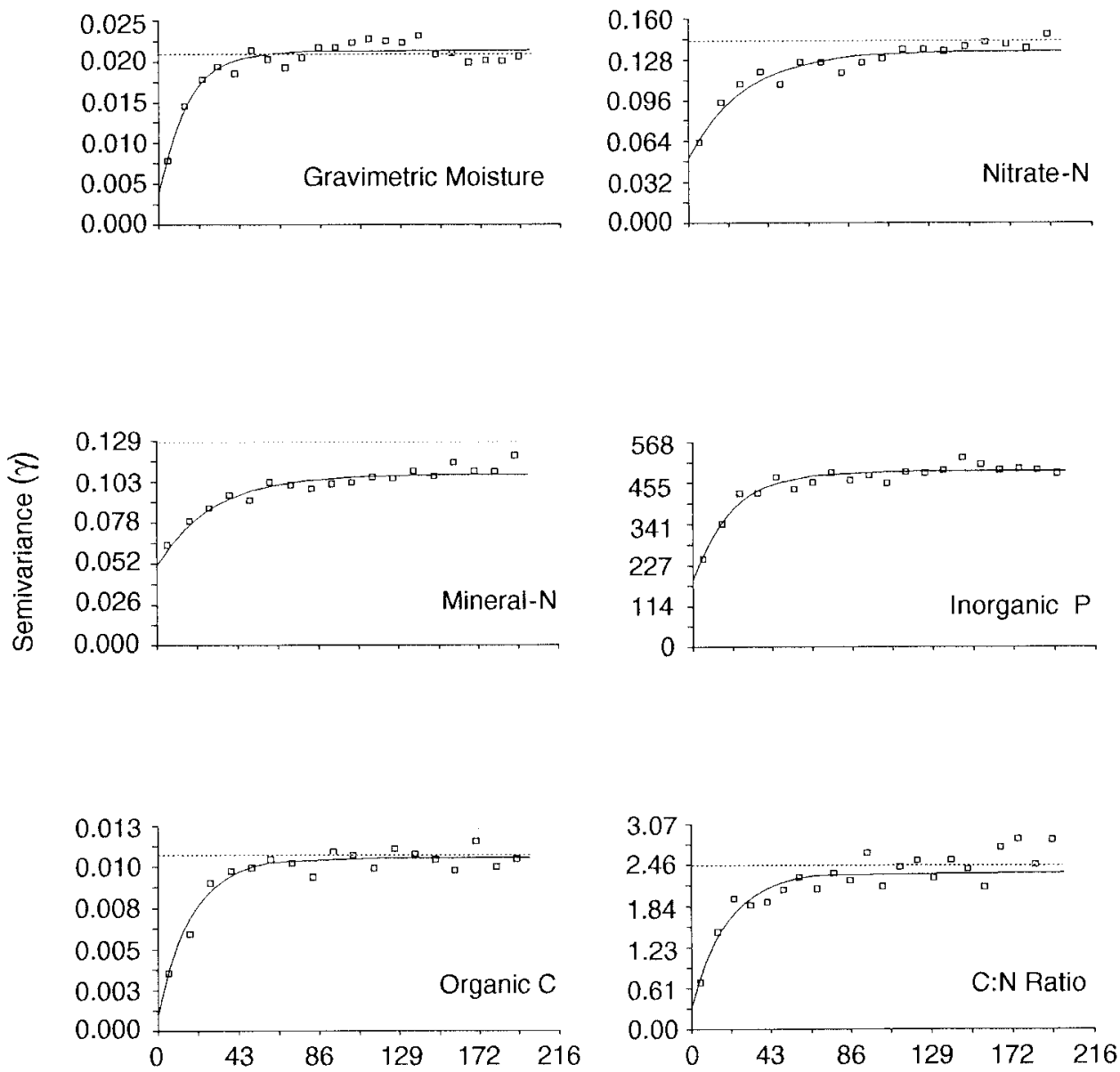

Distance Interval (m)

FIG. 4. Variograms for soil chemical characteristics across the site. Horizontal dotted lines in each diagram indicate overall sample variance for each variate except for inorganic P, for which $s^{2}=623.0$. Model parameters appear in Table 5 .

TABLE 5. Variogram model parameters for chemical characteristics of soil at the site. All models are exponential (formula in Table 4 footnote) except for acidity (formula in footnote \$). See Table 4 legend and Notes for further details.

\begin{tabular}{lcccc}
\hline \hline & \multicolumn{4}{c}{ Model parameters } \\
\cline { 2 - 5 } \multicolumn{1}{c}{ Property } & $\begin{array}{c}C /\left(C_{0}\right. \\
+C)\end{array}$ & $\begin{array}{c}\text { Range } \\
(\mathrm{m})\end{array}$ & $r^{2}$ & $s^{2}$ \\
\hline Moisture & 0.853 & 45.6 & 0.903 & $0.021 \dagger$ \\
Acidity (pH) & 0.757 & 62.6 & 0.985 & 0.219 \\
Nitrate N & 0.630 & 90.0 & 0.906 & $0.152 \dagger$ \\
Mineral N & 0.537 & 90.0 & 0.895 & $0.131 \dagger$ \\
Inorganic P & 0.756 & 53.7 & 0.927 & 599.0 \\
Organic C & 0.926 & 53.7 & 0.919 & $0.011 \dagger$ \\
C:N & 0.872 & 57.0 & 0.796 & 2.41 \\
\hline
\end{tabular}

$\dagger$ Following lognormal transformation where so noted in Table 2.

$\ddagger$ Nested model; parameters for first (spherical) 90 -m portion shown: for $h<$ range, $\gamma(h)=C_{0}+\left(C-C_{0}\right) \times(1.5 \times$ $h /$ range $)-0.5 \times(h / \text { range })^{3}$, for $h \geq$ range, $\gamma(h)=C$. site. Plant productivity (Fig. 9c) was also patchy, with somewhat higher values on the west side of the site. Maps for other properties (not shown) show similar levels of heterogeneity.

A number of soil properties were significantly correlated with peak plant biomass; these include soil nitrate pools $(r=-0.445, P<0.001)$, microbial biomass $(r=-0.320, P<0.001)$, gravel content $(r=-0.228$, $P<0.001)$, elevation $(r=0.204, P<0.001)$, bulk density $(r=0.181, P<0.001)$, clay content $(r=$ $-0.158, P<0.001)$, and total carbon $(r=-0.151$, $P<0.001$ ). Multiple regression analysis identified five of these and other variates that collectively can explain up to $42 \%$ of the variation in plant biomass across the site; these include soil nitrate, gravel content, inorganic $\mathrm{P}, \mathrm{N}$ mineralization, and $\mathrm{pH}$ (Table 7). Adding four additional variates (silt content, moisture, microbial biomass, and soil $\mathrm{C}: \mathrm{N}$ ratio) increased this proportion significantly but to $\leq 46 \%$. Principal components analysis of the non-plant variates, followed by linear regression of the first-principal-component coefficients 


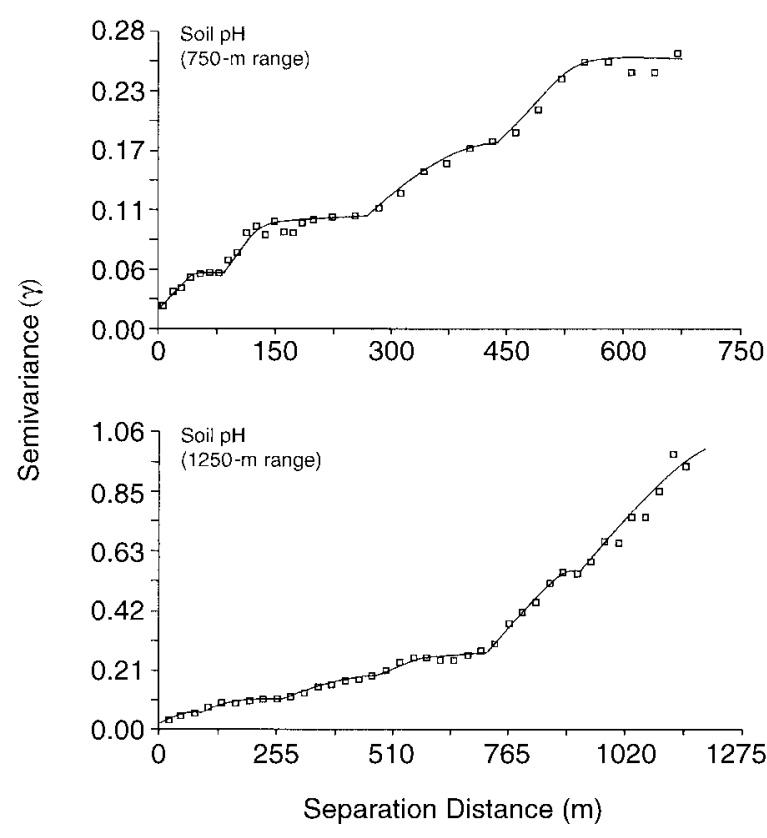

FIG. 5. Variogram for soil $\mathrm{pH}$ across 750-m range (upper graph), and across entire range available (lower graph). Model parameters for $0-75 \mathrm{~m}$ range appear in Table 5 .

against soybean biomass at each location, could explain only $44 \%$ of the variation in plant biomass across the site.

Soil microbial biomass also has a number of statistically significant soil-property correlates; these include elevation $(r=-0.502, P<0.001)$, total soil carbon $(r=0.367, P<0.001)$, soil nitrate $(r=0.293$, $P<0.001)$, soil moisture $(r=0.182, P<0.001)$, and soil respiration $(r=0.159, P<0.001)$. Multiple regression analysis shows that a combination of five variates (elevation, clay content, net nitrification, $\mathrm{pH}$, and sand content) can explain $\approx 50 \%$ of the variation in microbial biomass across the site (Table 7). Adding three additional variates (mineral $\mathrm{N}$, organic $\mathrm{C}$, and $\mathrm{C}$ : $\mathrm{N}$ ratio) can increase this proportion to $56 \%$.

\section{DISCUSSION}

We were surprised by the large amount of spatial heterogeneity in this 48-ha field. The site had been cleared of original vegetation and cultivated for perhaps $100 \mathrm{yr}$ prior to the start of this study, with much of this period in monoculture corn, soybean, or wheat crops. Visually the site appears to be as homogeneous as any agricultural field in the region. It is relatively level and of uniform soil color, and to the unpracticed eye shows no obvious trends in plant vigor. We thus did not expect to find differences of up to two orders of magnitude in important soil properties and resources across the site.

Spatial variability was high for virtually all soil, plant, and microbial properties that we examined. Coefficients of variation ranged from 40 to $90 \%$ for most variates, and in almost all cases this variability had a large spatial component. For most soil physical and chemical properties, for example, 50-90\% of apparent sample variance was spatially structured; for most biological properties spatial structure within a $20-90 \mathrm{~m}$ range accounted for $35-55 \%$ of total sample variance.

The proportion of sample variance not spatially structured in our models can be attributed to either measurement error or to spatial dependence at scales smaller than those examined in this field (Isaacs and Srivastava 1989). Theoretically, semivariance at a separation distance of zero should be nil since any variate at a given sample location is perfectly autocorrelated with itself, and thus the variogram model should pass through the origin. We believe measurement error was small in this study. In most cases values for properties at each location were based on three or more analytical replicates taken from a well-mixed or well-ground sample, and analytical variation above a CV of 5-10\% triggered either sample re-analysis or discard. We therefore attribute most if not all of the low apparent spatial dependence of variates such as microbial population size and soil microbial respiration to dependence at distances $<5 \mathrm{~m}$, the smallest average sample separation distance in this study. These small ranges for microbial processes are consistent with our subsequent samplings and with recent studies in other agricultural (Folorunso and Rolston 1985, Rochette et al. 1991) and desert (Smith et al. 1994, Schlesinger et al. 1996) ecosystems.

A second trend apparent from these analyses is the relatively short range over which spatial dependence occurred in this field. In all but three cases-elevation, soil $\mathrm{pH}$, and inorganic $\mathrm{P}$ - structural variance was limited to separation distances of $<100 \mathrm{~m},<10 \%$ of the total distance possible for this site. That model variance (the variogram asymptote or sill) approached total sample variance for the majority of variates (Figs. 2, 4, 6, 7 ) indicates that there is little spatial structure to sample variance beyond $100 \mathrm{~m}$ (Barnes 1991). Thus, for most variates, virtually all of the spatially structured variance that we detected occurred in effective patch sizes of $\leq 100 \mathrm{~m}$. Microbial properties were autocorrelated at even smaller scales: for microbial biomass, nitrification, and $\mathrm{N}$-mineralization, model ranges were on the order of 20-30 m.

We tested the likelihood that the range for some variates such as microbial population size and respiration was below our detection limits of $5 \mathrm{~m}$ by re-measuring soil respiration at $2.5-\mathrm{cm}$ distances along several $1-\mathrm{m}$ transects placed in the same field in July of the following year (L. Merrill, M. Cavigelli, and G. P. Robertson, unpublished data). The resulting variogram (Fig. 10) suggests that almost $100 \%$ of variation at this scale $(1 \mathrm{~m})$ is spatially dependent within a range of $<18 \mathrm{~cm}$. It seems likely that this is also the case for other variates, especially biological properties that may be controlled at the scale of a soil aggregate or the plant rhizosphere. In fact, periodicity apparent in the 

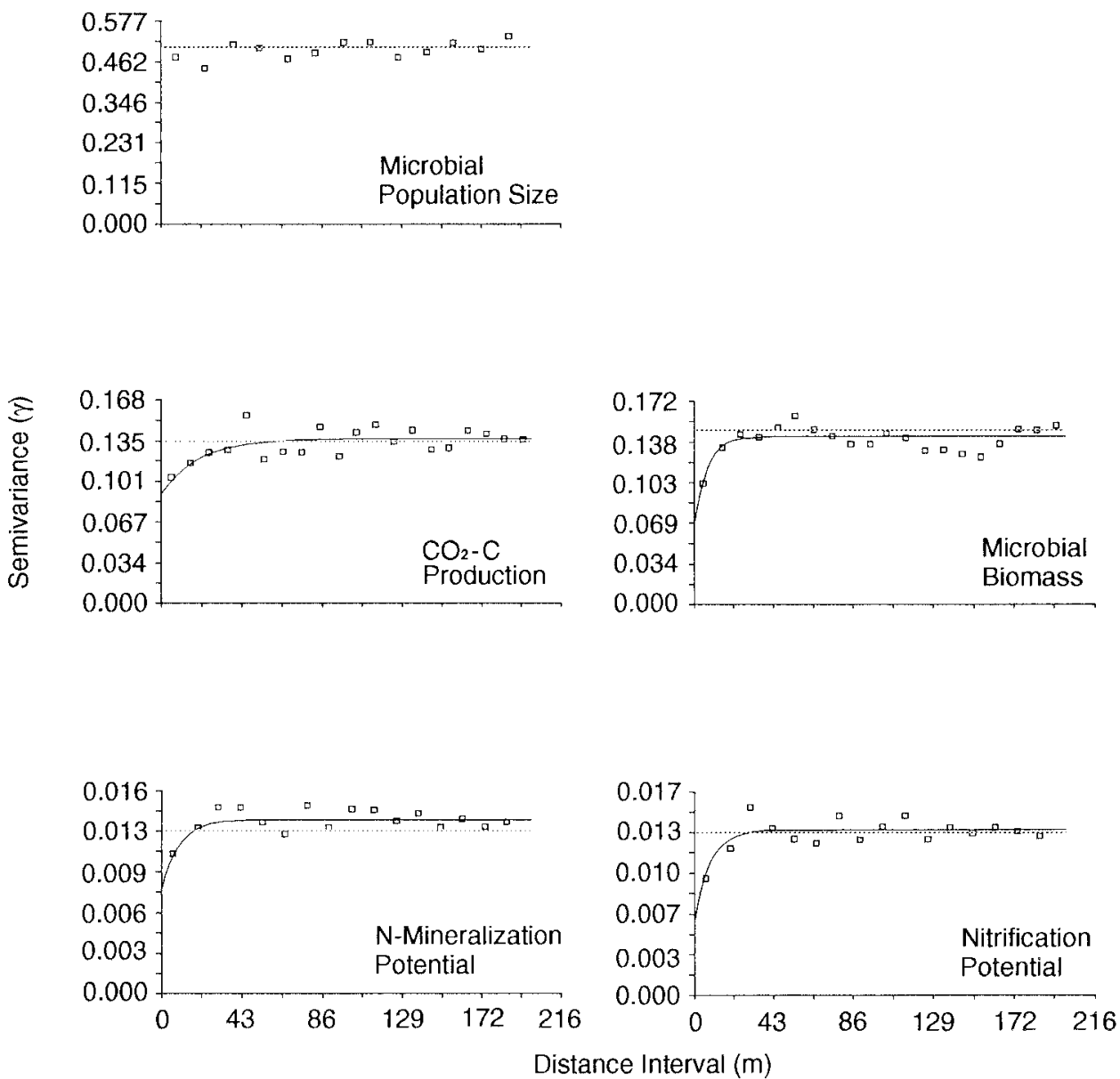

FIG. 6. Variograms for microbial properties across the site. Horizontal dotted lines in each diagram indicate overall sample variance for each variate. Model parameters appear in Table 6.

TABLE 6. Variogram model parameters for biological properties of soil at the study site. All models are exponential. See Table 4 Notes for further details. See Figs. 6 and 7 for variograms.

\begin{tabular}{|c|c|c|c|c|}
\hline \multirow[b]{2}{*}{ Property } & \multicolumn{4}{|c|}{ Model parameters } \\
\hline & $C /\left(C_{0}+C\right)$ & Range (m) & $r^{2}$ & $s^{2}$ \\
\hline \multicolumn{5}{|l|}{ Microbial properties } \\
\hline Culturable bacteria & -† & $-\dagger$ & -† & 0.511 末 \\
\hline Biomass C & 0.542 & 21.0 & 0.497 & $0.146 \%$ \\
\hline Respiration & 0.341 & 61.2 & 0.420 & 0.135 ₹ \\
\hline Net nitrification & 0.559 & 25.5 & 0.579 & $0.013 \|$ \\
\hline Net $\mathrm{N}$ mineralization & 0.407 & 28.4 & 0.483 & $0.013 \|$ \\
\hline \multicolumn{5}{|l|}{ Plant properties } \\
\hline Biomass & 0.440 & 93.0 & 0.855 & 6937. \\
\hline $\mathrm{N}$ content & 0.560 & 51.3 & 0.700 & 0.210 \\
\hline
\end{tabular}

$\dagger$ Spatial structure not apparent.

$\$$ Skewness and kurtosis calculated following lognormal transformation $[\ln (z)]$ of original values.

|| Skewness and kurtosis calculated following lognormal transformation $[\ln (z+1)]$ of original values. 


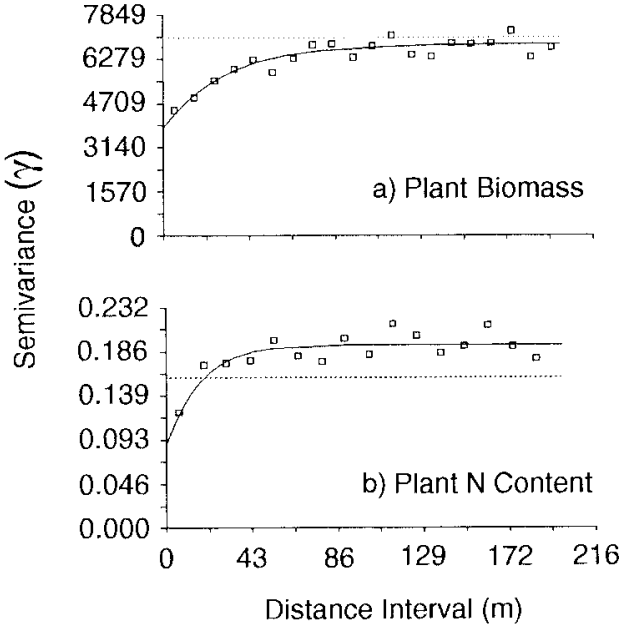

FIG. 7. Variogram for peak plant biomass and $\mathrm{N}$ content across the site. Other presentation information is as in Fig. 6.

small-scale $\mathrm{CO}_{2}$ variogram beyond $15 \mathrm{~cm}$ (data not shown) roughly corresponds to the $7.5-\mathrm{cm}$ spacing of corn plants in this field at the time of sampling, giving further credence (in this case) to a root-zone-influence explanation.

Elevation, soil $\mathrm{pH}$, and inorganic $\mathrm{P}$ were also different from other properties with respect to the range over which dependence was expressed. In addition to spatial structure at scales of $<100 \mathrm{~m}$, these variates also exhibited substantial spatial dependence at greater scales. In fact, in none of these cases did the variogram reach an asymptote for this site, indicating spatial structuring at ranges beyond the maximum distance examined $(1100 \mathrm{~m})$. Topographic relief, for example, exhibited strong dependence in the $<200 \mathrm{~m}$ range (Fig. 2 ), but this dependence was only a small proportion of that occurring over the entire range possible (Fig. 3). The isopleth of elevation across the site (Fig. 8a) illustrates this nesting: within a general trend of downward-sloping relief from the northwest corner to the southeast corner of the site, there is also significant complexity at smaller scales as illustrated in the isopleth for a smaller, 1-ha portion of the site (Fig. 11). Likewise, small-scale heterogeneity for soil $\mathrm{pH}$ is nested within a larger trend of lower $\mathrm{pH}$ at the north end of the site, as suggested by Fig. 5's illustration of autocorrelation distinctly nested at multiple scales within an overall range of $1100 \mathrm{~m}$.

Models of nested variance probably indicate multiple levels of control for soil properties (Burrough 1983, Robertson and Gross 1994). For soil pH, for example, we are likely seeing the influence of field-level cultural practices at the larger separation distances. The relatively low soil pH's at the northern end of the field probably result from a previous boundary; historical analysis subsequent to our mapping suggests that the northernmost portion of the field does in fact have a different crop and probably a different liming history.

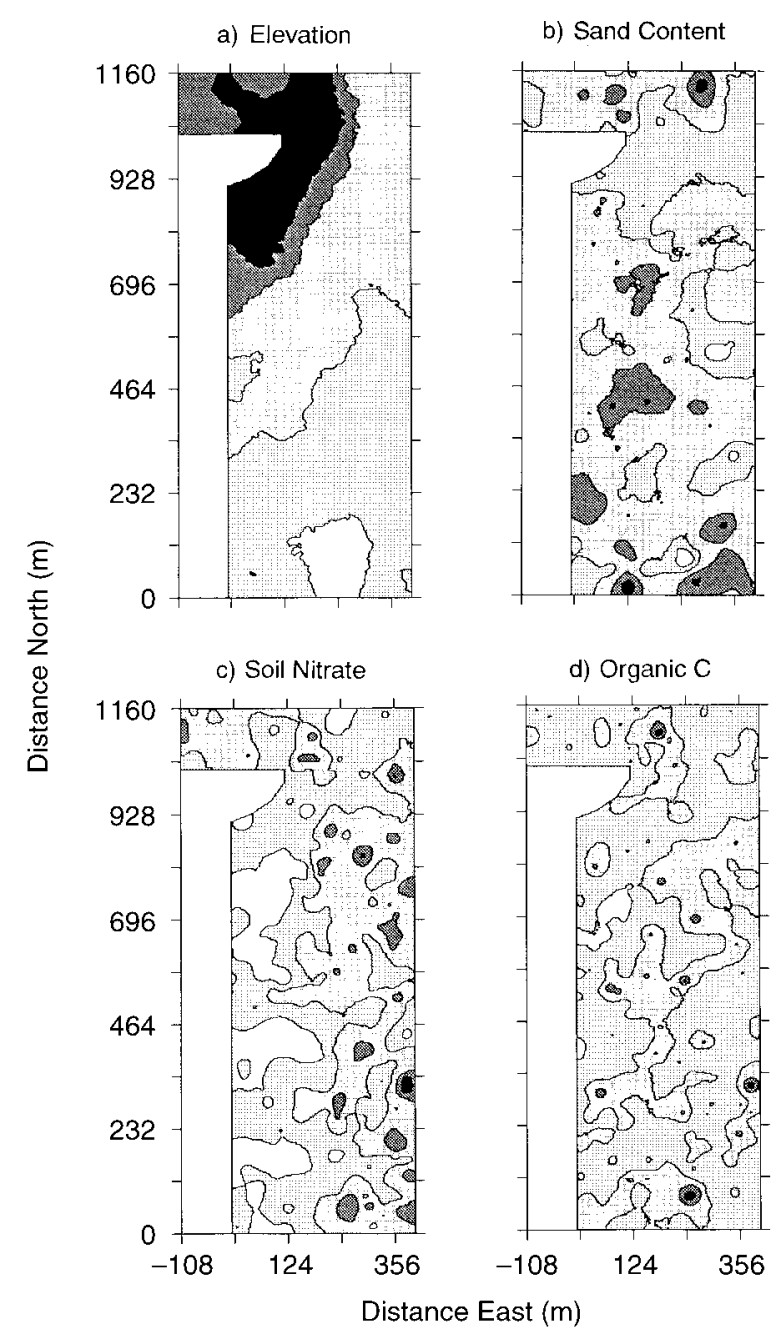

FIG. 8. Isopleths for selected soil physical and chemical properties across the site; shading patterns denote five equal increments in levels for a given property across its range: (a) topographic relief (285.3-291.4 m); (b) sand content (35.0$60.3 \%$ sand); (c) soil nitrate (5.7-15.1 mg N/g soil); and (d) total soil C $(0.85-1.93 \% \mathrm{C})$.

At intermediate ranges, geomorphological influences likely regulate spatial structuring, i.e., localized soil horizonation differences (Mokma and Doolittle 1993a) that result from differences in microtopography and erosion that may in turn lead to differences in soil $\mathrm{pH}$ as the $A_{p}$ horizon varies. At still smaller distances we might expect plant-canopy and eventually soil-aggregate and rhizosphere effects to structure variation. Although we did not evaluate the spatial structuring of $\mathrm{pH}$ at scales $<5 \mathrm{~m}$, it seems likely that the $30 \%$ of variance not spatially dependent within the first $60-\mathrm{m}$ range (Fig. 5) occurred at smaller scales in much the same way that it occurred for soil respiration (Fig. 10).

We were also surprised by the lack of overall correspondence between plant productivity and a host of soil properties. That any given combination of measured soil properties could explain no more than $46 \%$ 
a) Net N Mineralization

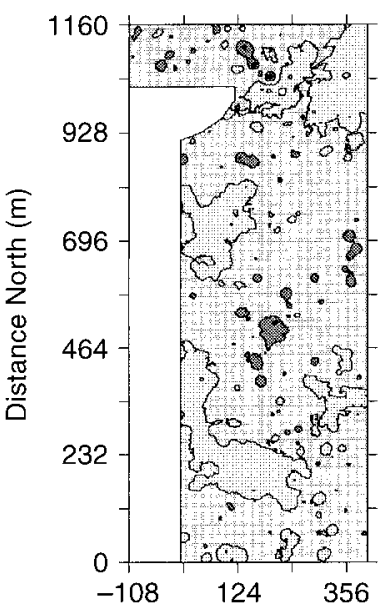

b) Microbial Biomass

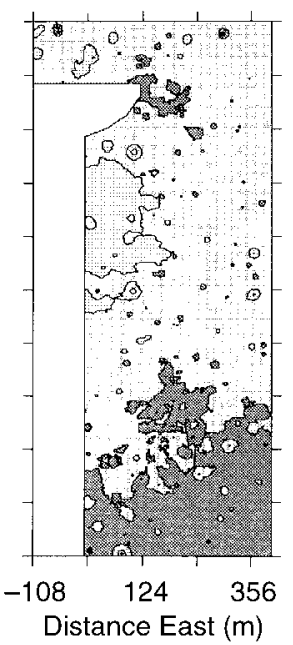

c) Peak Plant Biomass

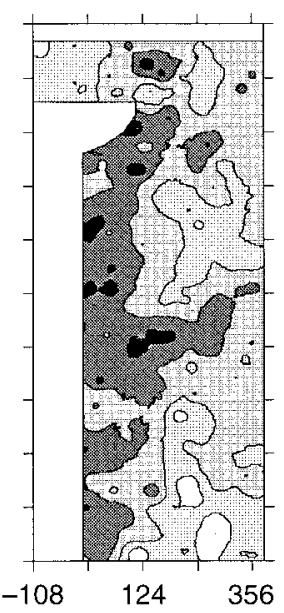

FIG. 9. Isopleths for selected biological attributes of the site; shading patterns denote five equal increments in levels for a given property across its range: (a) net $\mathrm{N}$ mineralization $\left(0.30-0.70 \mathrm{mg} \mathrm{N} \cdot \mathrm{g}^{-1} \cdot \mathrm{d}^{-1}\right)$; (b) microbial biomass $(39-95 \mathrm{mg} \mathrm{C} / \mathrm{g}$ soil); and (c) peak plant (soybean) biomass $\left(170-347 \mathrm{~g} / \mathrm{m}^{2}\right)$.

$(r=0.68$; Table 7$)$ of the variation in plant productivity across the site-despite the fact that productivity varied by more than an order of magnitude-defies conventional wisdom and bodes poorly for efforts to base sitespecific agronomic management strategies on isopleths of soil properties (e.g., Robert et al. 1993).

The most likely explanation for the poor correlation between plant production and soil properties is the role of temporal variability and its interaction with spatial heterogeneity. A number of the soil properties that we measured are relatively static (particle size density, for example), while others such as $\mathrm{N}$ and $\mathrm{C}$ availability are seasonally dynamic. Our sampling in late spring represents a one-time measure of variability across the

TABLE 7. Results of stepwise multiple regression analysis for peak soybean biomass and soil microbial biomass at a Michigan farmland site.

\begin{tabular}{lrc}
\hline \hline \multicolumn{1}{c}{ Predictors } & $\begin{array}{c}\text { Regression } \\
\text { coefficient }\end{array}$ & $\begin{array}{c}\text { Cumulative } \\
r^{2}\end{array}$ \\
\hline Peak soybean biomass & & \\
Nitrate-N & -0.508 & $0.198^{* * * *}$ \\
Bulk density (gravel content) & -0.295 & $0.313^{* * *}$ \\
Inorganic P & -0.337 & $0.347^{* * *}$ \\
$\mathrm{~N}$ mineralization & 0.229 & $0.386^{* * *}$ \\
$\mathrm{pH}$ & 0.226 & $0.416^{* * *}$ \\
Microbial biomass & & \\
Elevation & -0.618 & $0.252^{* * *}$ \\
Clay content & 0.629 & $0.378^{* * *}$ \\
Net nitrification & 0.357 & $0.424 * * *$ \\
Soil pH & 0.342 & 0.449 \\
Sand & 0.263 & 0.493 \\
\hline Note: Only the top five predictors are listed; inclusion of \\
all significant predictors brings the cumulative amount of \\
variation accounted for to $r^{2}=0.460$ for peak soybean bio- \\
mass (nine predictors) and $r^{2}=0.56$ for microbial biomass \\
(eight predictors). \\
$* P \leq 0.001$.
\end{tabular}

site. This "snapshot" is likely to be sufficient for assessing the impact of temporally invariant properties such as soil texture on primary productivity, and regression analysis probably reported the influence of these properties correctly. For seasonally dynamic properties, however, contributions to productivity may be reflected accurately only by a seasonal integration of values rather than a single sampling early in the season, as an early season value at a given location may not be a sufficiently accurate indicator of a property's total season influence. And even a seasonal integration may be insufficient for judging the effect of properties that may be influential for a fairly transient period, e.g., soil water availability during a mid-season drought or soil nitrogen availability during the few weeks of exponential crop growth. In these cases, it may be necessary to gather necessary information during a critical period that may be difficult to identify a priori, especially if interactions among factors (water,

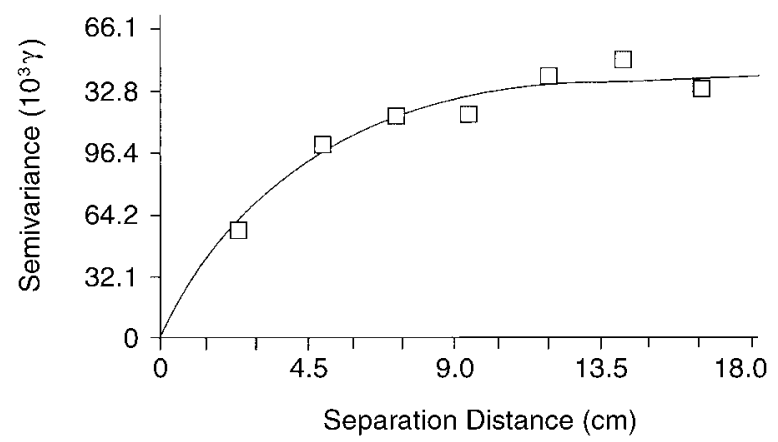

FIG. 10. Variogram for soil respiration along one of three 1 -m transects sampled every $2.5 \mathrm{~cm}$ within a portion of the site planted to corn. 


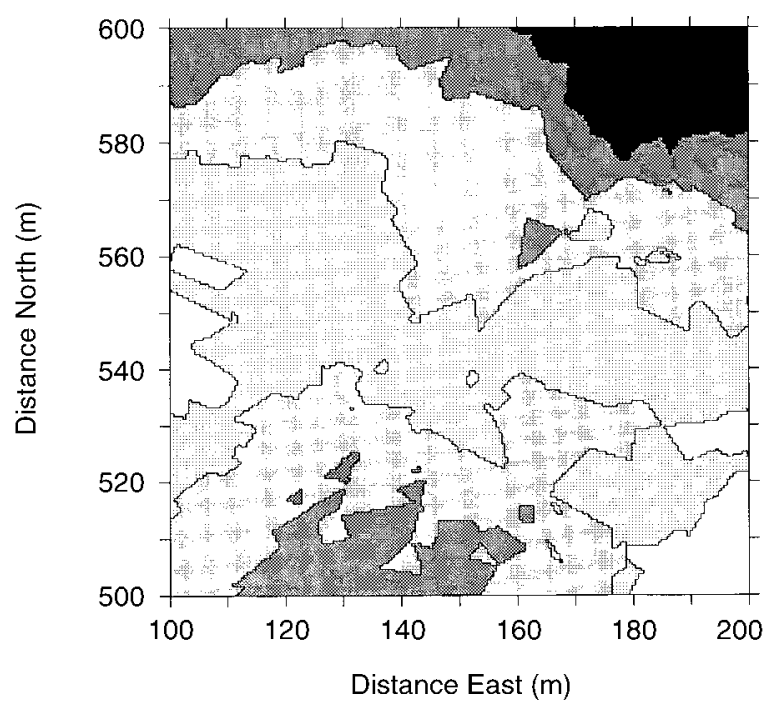

FIG. 11. Topographic relief within a 1-ha portion of the site; shading patterns denote five even increments in elevation between values of $286.96 \mathrm{~m}$ (lighter shading) to $287.24 \mathrm{~m}$ (black shading).

nitrogen, and microbial activity, e.g.) also change during these periods.

Based on our findings, then, we are not hopeful that site-specific management decisions in agriculture can be based solely or even mainly on measurements of soil properties that can vary seasonally. While such indices have been very useful indicators of soil fertility at large scales (e.g., soil nitrate tests in early spring used to gauge crop N-fertilizer needs across U.S. counties), within individual geomorphic units these indices are likely to be less useful because of finer scale temporal interactions. At within-field scales it is more likely that prior-season yield maps, together with information about invariant soil physical properties such as texture, will provide more useful information at lower cost. Such maps allow the crop itself to do the integrating.

Taken together with other studies of soil resource heterogeneity, our results provide further evidence that soils in a wide variety of ecosystems are highly structured spatially, and that this structuring should be considered when designing both experiments and management strategies. Although knowledge about the heterogeneity of some properties at a specific point in time may be insufficient to guide management decisions later, it is nevertheless apparent that spatially explicit information about some properties (e.g., soil texture or yield) should be useful to managers whenever it is available. Knowledge of the spatial heterogeneity of more dynamic properties will be of less use to managers but nevertheless of substantial value to those attempting to understand the dynamics of specific populations and processes within ecosystems at large.
ACKNOWLEDGMENTS

We are indebted to many who helped with field, laboratory, and computational analyses during the course of this study. In particular we would like to thank S. J. Halstead, J. Hamelink, W. P. Horwath, L. Krievs, A. LaChance, and G. Walker for their exceptional field and laboratory efforts, K. L. Gross, M. A. Cavigelli, and A. J. Tessier for helpful discussions during the computation and interpretation phase, R. Webster for advice on sampling strategies, and editor W. H. Schlesinger and two anonymous reviewers for many helpful comments on an earlier draft. This work was supported by funding from the NSF LTER Program (BSR 87-02332) and the Michigan Agricultural Experiment Station.

Data used in this study are available electronically as part of the KBS LTER Site permanent data archives. Data may be downloaded from the KBS LTER World Wide Web server at http://kbs.msu.edu/lter/.

\section{Literature Cited}

Alpkem. 1992. The flow solution operation manual. Alpkem, Wilsonville, Oregon, USA.

Barnes, R. J. 1991. The variogram sill and the sample variance. Mathematical Geology 23:673-678.

Burrough, P. A. 1983. Multiscale sources of spatial variation in soil. The application of fractal concepts to nested levels of soil variation. Journal of Soil Science 34:577-597.

Collins, H. P., G. P. Robertson, and M. J. Klug, editors. 1995. The significance and regulation of soil biodiversity. Kluwer Academic, Dordrecht, The Netherlands.

Cressie, N. 1985. Fitting variogram models by weighted least squares. Mathematical Geology 17:563-586.

Crum, J. R., G. P. Robertson, and F. Nurenberger. 1990. Long-term climate trends and agricultural productivity in Southwestern Michigan. Pages 53-58 in D. Greenland and L. W. Swift, editors. Climate variability and ecosystem response. U.S. Forest Service, U.S. Department of Agriculture, Washington, D.C., USA.

Fiez, T. E., B. C. Miller, and W. L. Pan. 1994. Assessment of spatially variable nitrogen fertilizer management in winter wheat. Journal of Production Agriculture 7:86-93.

Folorunso, O. A., and D. E. Rolston. 1985. Spatial variability of field-measured denitrification gas fluxes. Soil Science Society of America Journal 48:1214-1219.

Gamma Design. 1995. GS+: geostatistical software for the agronomic and biological sciences, version 2.3. Plainwell, Michigan, USA.

Gross, K. L., K. S. Pregitzer, and A. J. Burton. 1995. Spatial variation in nitrogen availability in three successional plant communities. Journal of Ecology 83:357-367.

Hook, P. B., I. C. Burke, and W. K. Lauenroth. 1991. Heterogeneity of soil and plant $\mathrm{N}$ and $\mathrm{C}$ associated with individual plants and openings in North American shortgrass steppe. Plant and Soil 138:247-256.

Horwath, W. R., and E. A. Paul. 1994. Microbial biomass in microbiological and biochemical properties of soil. Pages 753-772 in R. Weaver, P. Bottomly, and S. Angle, editors. Methods of soil analysis, part 2. Microbiological and biochemical properties. Soil Science Society of America, Madison, Wisconsin, USA.

Horwath, W. R., E. A. Paul, J. Norton, D. Harris, L. Jagger, and K. Horton. 1997. Defining a realistic control for the chloroform fumigation incubation method. Canadian Journal of Soil Science, in press.

Isaacs, E., and R. Srivastava. 1989. An introduction to applied geostatistics. Oxford University Press, New York, New York, USA.

Jackson, R., and M. Caldwell. 1993. The scale of nutrient heterogeneity around individual plants and its quantification with geostatistics. Ecology 74:612-614.

Krige, D. G. 1981. Lognormal-d Wijsian geostatistics for ore 
evaluation. South African Institute of Mining and Metallurgy Monograph Series Geostatistics 1:1-51.

Kuchler, A. W. 1964. Potential Natural Vegetation of the Conterminous United States. Geography Society Special Publication 36, New York, New York, USA.

Lechowicz, M. J., and G. Bell. 1991. The ecology and genetics of fitness in forest plants. II. Microspatial heterogeneity of the edaphic environment. Journal of Ecology 79: 687-696.

Mokma, D. L., and J. A. Doolittle. 1993a. Mapping soils and soil properties in southwest Michigan using groundpenetrating radar. Soil Survey Horizons 34:13-22.

Mokma, D. L., and J. A. Doolittle. 1993b. Mapping some loamy alfisols in southwestern Michigan using ground-penetrating radar. Soil Survey Horizons 34:71-77.

Olsen, S. R., and L. E. Sommers. 1982. Phosphorus. Pages 403-430 in A. L. Page, R. H. Miller, and D. R. Keeney, editors. Methods of soil analysis part 2: chemical and microbiological properties. Second edition. American Society of Agronomy, Madison, Wisconsin, USA.

Robert, P. C., R. H. Rust, and W. E. Larson, editors. 1993. Soil specific crop management. American Society of Agronomy, Madison, Wisconsin, USA.

Robertson, G., M. Huston, F. Evans, and J. Tiedje. 1988. Spatial variability in a successional plant community: patterns of nitrogen availability. Ecology 69:1517-1524.

Robertson, G. P., J. R. Crum, and B. G. Ellis. 1993. The spatial variability of soil resources following long-term disturbance. Oecologia 96:451-456.

Robertson, G. P., and D. W. Freckman. 1995. The spatial distribution of nematode trophic groups across a cultivated ecosystem. Ecology 76:1425-1432.

Robertson, G. P., and K. L. Gross. 1994. Assessing the heterogeneity of below-ground resources: quantifying pattern and scale. Pages 237-253 in M. M. Caldwell and R. W. Pearcy, editors. Plant exploitation of environmental heterogeneity. Academic Press, New York, New York, USA.

Rochette, P., L. R. Desjardins, and E. Patty. 1991. Spatial and temporal variability of soil respiration in agricultural fields. Canadian Journal Soil Science 71:189-196.

Rossi, R. E., D. J. Mulla, A. G. Journal, and E. H. Franz. 1992. Geostatistical tools for modeling and interpreting geological spatial dependence. Ecological Monographs 62: 277-314.

SAS Institute. 1985. SAS user's guide. Statistics, version 5. SAS Institute, Incorporated, Cary, North Carolina, USA.

Schlesinger, W. H., J. F. Reynolds, G. L. Cunningham, L. F. Huenneke, W. M. Jarrell, R. A. Virginia, and W. G. Whitford. 1990. Biological feedbacks in global desertification. Science 247:1043-1048.

Schlesinger, W. H., J. A. Raikes, A. E. Hartley, and A. F. Cross. 1996. On the spatial pattern of soil nutrients in desert ecosystems. Ecology 77:364-374.

Smith, J. L., J. L. Halvorson, and H. J. Bolton. 1994. Spatial relationships of soil microbial biomass and $\mathrm{C}$ and $\mathrm{N}$ mineralization in a semi-arid shrub-steppe ecosystem. Soil Biology and Biochemistry 29:1151-1159.

Tilman, D., and D. Wedin. 1990. Species effects on nitrogen cycling: a test with perennial grasses. Oecologia 84:433441.

Walker, P. H., and R. V. Ruhe. 1968. Hill slope models in soil formation. II. Closed systems. Transactions of the Ninth International Congress of Soil Science (Adelaide, Australia) 4:561-569.

Webster, R. 1985. Quantitative spatial analysis of soil in the field. Pages 1-70 in B. A. Stewart, editor. Advances in soil science. Springer-Verlag, New York, New York, USA.

Webster, R., and M. Oliver. 1990. Statistical methods in soil and land resource survey. Oxford University Press, Oxford, England.

Whiteside, E., I. Schneider, and R. Cook. 1959. Soils of Michigan. Michigan State University Agricultural Experiment Station Special Bulletin $\mathbf{4 0 2}$.

Wilkinson, L., M. Hill, J. P. Welna, and G. K. Birkenbeuel. 1992. SYSTAT for Windows. SYSTAT, Evanston, Illinois, USA. 